\title{
Architecture_MPS
}

\section{Landscape and Consumer Culture in the Design Work of Humphry Repton and Gordon Cullen: A Methodological Framework}

Mira Engler*, ${ }^{1}$

How to cite: Engler, M. 'Landscape and Consumer Culture in the Design Work of Humphry Repton and Gordon Cullen: A Methodological Framework.'

Architecture_MPS, 2018, 13(1): 2. DOI:

https://doi.org/10.14324/111.444.amps.2018v13i2.001.

Published: 09 March 2018

\section{Peer Review:}

This article has been peer reviewed through the journal's standard double blind peer-review, where both the reviewers and authors are anonymised during review.

\section{Copyright:}

(c) 2017, The Author(s). This is an Open Access article distributed under the terms of the Creative Commons Attribution License (CC-BY) 4.0 https://creativecommons.org/licenses/by/4.0/, which permits unrestricted use, distribution and reproduction in any medium, provided the original author and source are credited • DOI: https://doi.org/10.14324/111.444.amps.2018v13i2.001.

\section{Open Access:}

Architecture_MPS is a peer-reviewed open access journal. 


\section{Amps}

\section{Title: Landscape and Consumer Culture in the Design Work of Humphry Repton and Gordon Cullen: A Methodological Framework}

\section{Author: Mira Engler}

Architecture_media_politics_society. vol.13, no. 2.

March 2018

Affiliation: Landscape Architecture, Iowa State University

\section{Abstract}

The practice of landscape and townscape or urban design is driven and shaped by consumer markets as much as it is by aesthetics and design values. Since the 1700s gardens and landscapes have performed like idealized lifestyle commodities via attractive images in mass media as landscape design and consumer markets became increasingly entangled. This essay is a methodological framework that locates landscape design studies in the context of visual consumer culture, using two examples of influential and media-savvy landscape designers: the renowned eighteenth-century English landscape gardener Humphry Repton and one of Britain's top twentieth-century draftsmen and postwar townscape designers, Gordon Cullen. Rather than aesthetics and meaning, I focus on the designer's motives, working modes, and visual marketing strategies for building audiences and markets. At the heart of these strategies is the performance of images in consumerist culture. Drawing on primary and secondary sources, I show that they persuasively fashioned, "packaged," and "sold" their landscape commodity through attractive and marketable image-text products. The study highlights the specific role that each man assumed vis-à-vis his work environment and consumers, the pictorial sources that each used, and the media that broadcast and shaped each designer's legacy. Despite the different historical contexts and the particular logics of the economy and mass media apparatuses of the time, this consumerist-focused study also reveals parallels between these men's motives and image-making and marketing strategies. For instance, their drive

DOI: 10.14324/111.444.amps.2018v13i2.001, ( 2018 , The Author. This is an Open Access article distributed under the terms of the Creative Commons Attribution License, which permits unrestricted use, distribution, and reproduction in any medium, provided the original author and source are credited. 


\section{Amps}

for both professional and laypeople appeal led them to bridge theory and practice, use the "art of compromise," and devise palatable and alluring images. By using consumerist arts perspectives in landscape and urban design studies, I offer a new interpretive path toward a historical knowledge that incorporates the landscape designer's modus operandi and explains the role of mass media and marketing in the production and consumption of landscape. 


\title{
Title: Landscape and Consumer Culture in the Design Work of Humphry Repton and Gordon Cullen: A Methodological Framework
}

\author{
Author: Mira Engler \\ Architecture_media_politics_society. vol. 13, no. 2.
}

March 2018

\section{Landscapes as Idealized Commodities in Consumerist Culture}

In his introduction to Sketches and Hints on Landscape Gardening (1794), the renowned eighteenth-century landscape gardener Humphry Repton explained that his original intent was to publish a complete guide to landscape gardening with general rules and multiple plates. However, because of cost and in the interests of time, he settled on a book of landscape gardening principles supported by one project example - that of Welbeck for the Duke of Portland - with excerpts, or "detached fragments" in his words, from many of his private design proposals featured in his Red Books. ${ }^{1}$ The 250 copies of Sketches and Hints sold for an exorbitant $2 \frac{1 / 2}{2}$ guineas apiece. Twelve years later, for a new edition, Repton pledged to reduce its cost - by avoiding expensive engravings - and thus reach a wider and more diverse audience. ${ }^{2}$ The marketing tactics and desire to expand and build new audience reflected the entrepreneurial shrewdness and publicity venture at the basis of Repton's enduring influence on landscape architectural practice. His influence hinged on advances in print technology and circulation and can be seen in the impact of his design message and principles as well as in the adoption of his representation techniques by many of his followers. Like Repton, other influential landscape and townscape designers used visual marketing strategies to rise above their many competitors and make their mark on the history of the profession.

The practice of landscape design is driven and shaped by consumer markets as much as it is by aesthetics and design values. Since the 1700s landscapes have performed as idealized commodities via attractive images in mass media as landscape design and consumerism became increasingly intertwined. Landscapes are part of the cultural economy, which comprises all those 


\section{Amps}

sectors in modem capitalism that cater to consumer popular demands for amusement, adornment, self-affirmation, and social status and display. ${ }^{3}$ Mass media, visual marketing, and advertising are necessary correlates of this cultural economy. Yet despite this logic, consumerist aspects largely have not received due diligence in landscape and garden design history scholarship as a vital framework of inquiry.

\section{Interpretive Frameworks in Landscape and Garden History}

Existing landscape and garden histories span a wide range of interpretive frameworks - from geomorphological, spatial, and typological analyses; to technological and natural condition studies; to image-based art and architectural aesthetic studies; to iconographic and symbolic frameworks; to textbased hermeneutics; to experiential descriptions based on psychology and perception; to botanical and horticultural probes; to social-anthropological inquiries. The latter framework involves varied foci, such as ideological and political, cultural values and meanings, class, and lifestyle. ${ }^{4}$ Moreover, in contrast to most approaches, which focus on the built landscapes (or its remains) and the users who inhabit them, the social-anthropological approach, instead, focuses on the creators of landscapes - their cultural background, and the experiences and discourses through which they acquired their knowledge and on the relationship between the designers and gardeners, clients, and users. Within the social-anthropological approach, an interpretive framework that more fully examines the creator's working modes and the commercial aspects of the production and consumption of landscapes is missing.

To fill this gap, I propose an interpretive framework that examines the interplay between landscape design and consumer culture. Rather than exploring the conditions, experience, aesthetics, and meaning of the built landscape, I focus on the designer's motives, working modes, and visual marketing strategies for building audiences and markets which yield wider and lasting influence. At the heart of these strategies is the performance of images in consumerist culture - how the tactics embedded in drawings and "visual products" have operated in the competitive marketing environment that "sells" landscape lifestyle or attitude and ultimately shapes the landscape. Furthermore, key to this approach is the interface between the production and reception of the work, that is, between the creator, the finance, the client, and the audience (i.e., readership).

To demonstrate this framework I use two examples: Humphry Repton, who shaped landscape design practice and discourse in Georgian England through over 400 design proposals, including over 200 illustrated reports, known as Red Books, and five commercial books on theory and practice; ${ }^{5}$ and Gordon Cullen, one of Britain's best-known twentieth-century architectural draftsmen, who shaped postwar urban landscape design practice with his 1961 book, Townscape, and its 1971 abridged edition, The Concise Townscape. For both men, drawings and publicity were key to success. 
The theoretical apparatus I use relies on literature that critically examines the cultural relationship between media, consumer culture, and design representation. This includes literature in cultural theory and criticism, media theory, and landscape, garden, architecture, and urban theory. I rely on the situationist and cultural critic Guy Debord's theory of consumer culture and the spectacle society as well as on the architectural critic Adrian Forty's study of consumerist objects of desire. ${ }^{6}$ From these standpoints, the production of landscapes and townscapes is viewed as a symptom of the logic of the emerging capitalist economy and visual culture at the time. My analysis extends from the cultural-economic level to mass media and publicity as well as representation in architectural theory. In this I rely heavily on the theoretical armature established by the architectural critic Beatriz Colomina, who focused the agency of media and representation in the architectural production. ${ }^{7}$ Colomina further examined the designer's modus operandi in relation to notions of publicity, consumerism, and audience in the work of Le Corbusier. I am also guided by the art historian Catherine de Smet's examination of graphic and publishing tactics in relation to readership practices in the work of Le Corbusier. ${ }^{8}$

Scholarship of landscape and garden have largely considered designers within the development of theories of landscape and garden ideas. Of the vast literature on Repton's life and work, however, a handful of scholars examined his image-making in the context of the nascent consumer culture. The foremost authority on garden and landscape history, John Dixon-Hunt's keen observations of Repton's acute sensibilities of the budding landscape gardening profession and of changes in taste greatly informed my work. ${ }^{9}$ I also build on the work of the landscape historian Stephen Daniels and the art historian André Rogger. ${ }^{10}$ Daniels highlighted the cultural and physical regimes that shaped Repton's work, including finance, class, and lifestyle. Finally, Rogger specifically examined Repton's drawings and texts within the contemporary architectural and art discourses and representations. Rogger's focus on the ways in which contemporary literary and pictorial genres shaped and, in turn, were shaped by Repton's Red Books as well as his focus on the reception contexts of these books, were instrumental to my work.

Urban design scholarship, likewise, has largely studied the work of Cullen within the autonomous development of theories of architectural and urban design ideas. It is also often tempered by moral and intellectual assessment. ${ }^{11}$ An exception is the urban design theorist Bob Jarvis who shifted the focus to Cullen's product - his book, Townscape - and analyzed the book itself as a designed object that is above all a system of representation. Jarvis reframed Cullen's primary product among postmodern literary notions of authorship and readership.

The intention here is to replicate none of these approaches, but to draw upon and inform them within a thesis which relates ideas about landscape representation and modes of architectural production and consumption to ways in which landscapes are appreciated and historicized. I focus on assessing 


\section{Amps}

Repton and Cullen as draftsmen, publicists, and visual marketers. Both men intended their "merchandise" to reach the broadest possible audience. By considering Repton and Cullen apart from landscape and urban design ideas, and by focusing on their role and production in the broader cultural system, I aim not only to present these men anew, but also to explore how landscape and townscape drawings and books functioned and, more speculatively, how consumerist design strategies helped construct the rural and urban landscape.

\section{Why These Two Men? Backgrounds and Motives}

Working two centuries apart, each man has made an indelible mark on their respective profession's history. Each has occupied a pivotal moment in the history of consumer culture. Repton (1752-1818) coincided with the birth of landscape gardening during the emergence of the modern consumer, the new suburbanite bourgeoisie, and the public sphere in mid-eighteenth century England. Cullen (1914-1994) emerged during the postwar expansion of landscape architecture into urban and suburban design, the explosion of consumerism and illustrated magazines, and the emergence of the popular sphere with the rise of TV culture and advertising. Both men rose above their competitors and spread their ideas far and wide, thus not only promoting their work (and business) and professions but also shaping the consumption of landscapes.

The study shows differences in the specific roles that each man assumed vis-à-vis the work environment and consumer, the relations between drawing techniques and available technology, and the workings of the media apparatus responsible for each man's publicity. Yet despite the different historical contexts and the particular logic of the economy and mass media of the time, this consumerist-focused study reveals parallels in these men's motives and marketing strategies. For instance, both men prove to have been visual communicators and salesmen, practical men of compromise rather than men of principle, and with an instinct for the psychology of the consumer. Additionally, both were adept at printing and media technologies. There are also similarities in the systems of representation and pictorial techniques that each man used to reach both professional and lay audiences. For instance, both relied on perspective sequence, elements of motion and time, and a mixture of lowbrow and highbrow pictorial and textual genres.

The two men began their careers after trying their hand in other, mostly commercial areas, and brought their business propensity to landscape/townscape design. Repton started in textile mercantile. He often sketched the surrounding countryside and sold local landowners watercolor views of their estates (Figure 1). After quitting the textile business, he turned his pastime pursuit to his primary source of income, producing paintings and theater set designs. He also tried his hand as playwright and critic. In 1788, at the age of 37 , he decided "to render [his] leisure profitable" and become a professional "landscape gardener." ${ }^{\prime 2} \mathrm{He}$ became a celebrated public figure, whose name 


\section{Amps}

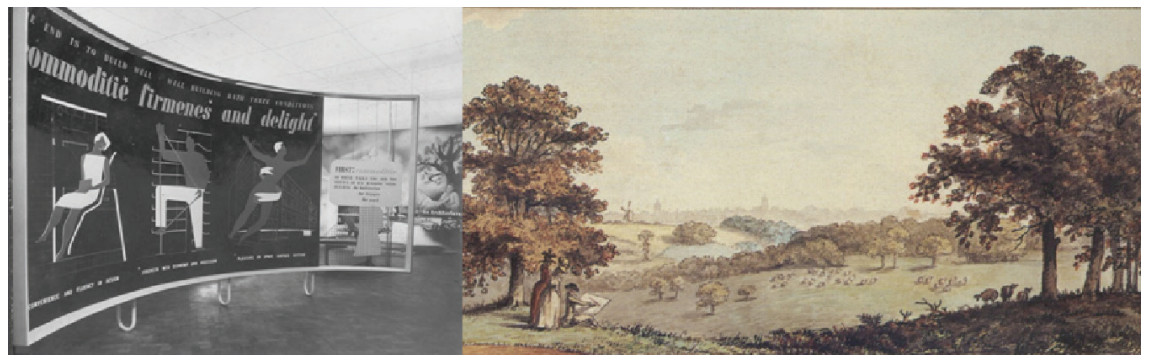

Figure 1. Cullen, exhibition panel, 1938-9. Source: Cullen personal archive (left). Repton, early watercolor illustration, "Catton Park" with Norwich in the distance, 1788 (right). Source: Norfolk Museums Service.

circulated in living-room conversation (and in Jane Austen's novels), among the nobility and new bourgeoisie in Georgian England. ${ }^{13}$

Cullen transferred from the London School of Arts and Crafts to Regent Street Polytechnic because "it promised higher earnings." 14 He graduated the three-year program of architectural draftsmanship at the height of the Depression in 1933, and began his career as freelance commercial artist and as architectural draftsman in top-ranked modernist architectural offices in London (Figure 1). His freelance illustrations appeared in notable professional books and publications and key national exhibitions as well as in product catalogues and newsprint advertising. This early work led to his being hired at the top architectural journal, The Architectural Review (the Review) in 1946, where he served as art editor from 1947 to 1959, and published extensively, both illustrations and essays. He became the de facto Townscape designer at the journal at age 34. After leaving the Review in 1960, his drawings and pictorial essays assembled in a book form became central to the discourse on the postwar city.

The two men commanded the business rules of their vocation and used the power of images to advance their status and profession. Repton promoted his trade's nomenclature and invented its rules. He called himself "landscape gardener" to distinguish himself from a gardener, and as a way to affiliate with a landscape painter (landscape gardening would evolve into the profession of landscape architecture). ${ }^{15}$ Accordingly, Repton was neither a gardener who executed gardens, as did Henry Wise, nor a contractor who supervised laborers, the way his predecessor Capability Brown did. He was also the first landscape professional to package his design proposal as a book product (i.e., Red Book), and he inserted his business card inside the front or back cover of his book (see Figure 5). He was a landscape consultant, draftsman, and publicist who drew (and wrote) to communicate his ideas about landscapes (Figure 2).

Cullen helped shaped the position of art editor at the Review. He expanded the typical range of graphic design tasks - illustrations, page layout, issue cover, and frontispiece design - into urban design, journalism, photography, and visual education. Despite his lack of training in these fields, especially 


\section{Amps}

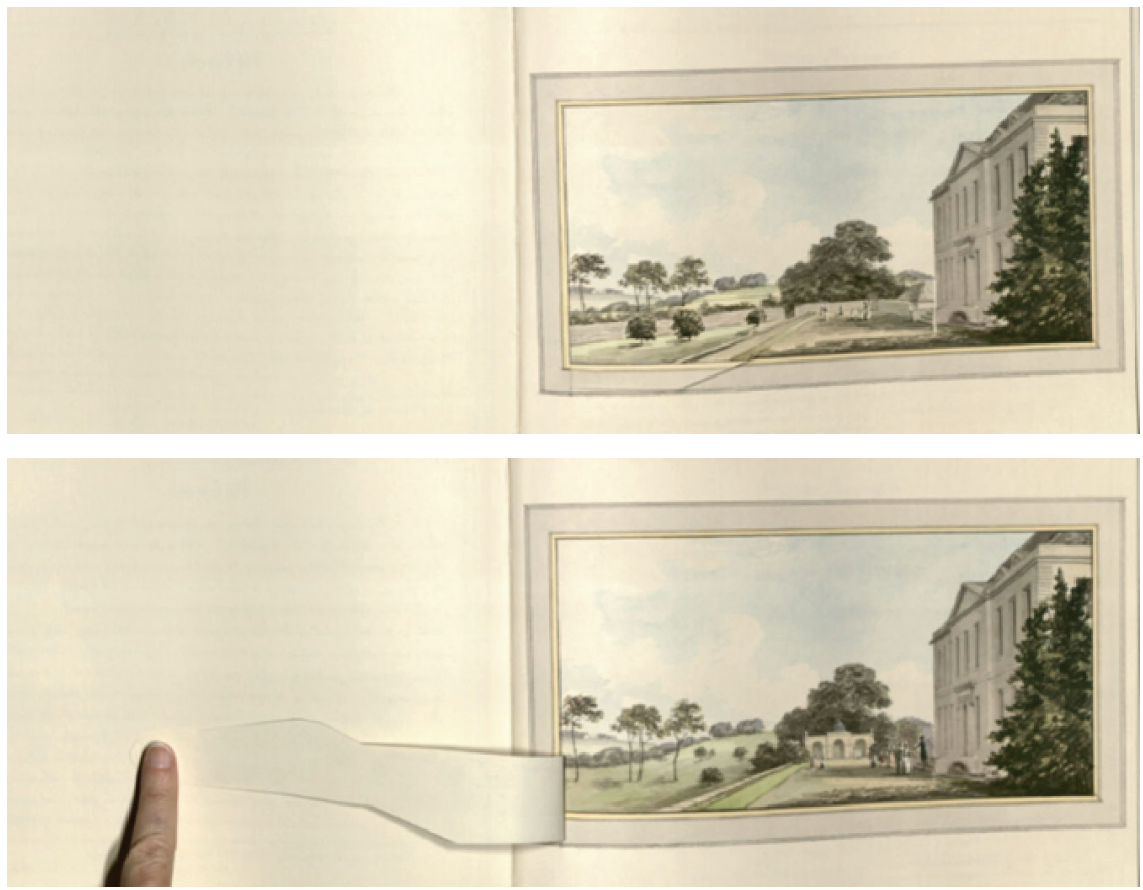

Figure 2. Repton, Red Book for Anthony House, two page spreads showing "before-and-after" scenes with the flap lifted, 1793. Public domain.

architecture and town planning proper, Cullen became the leading Townscape designer. His numerous illustrations, frontispieces and covers, pictorial essays, and town design proposals adorned the magazine and translated for practitioners and lay people alike the Townscape principles conceived by the journals' editors (Figure 3). ${ }^{16}$ Cullen has often been slighted for not producing original content, but it is his pictorial translation and colloquial language of Townscape, rather than the texts of his erudite colleagues, that have reached a wide audience and had a sustained influence. Cullen drew and accompanied his pictorial work with expanded captions and figurative text, and used the platform of the Architectural Press (the publishing house of the Review) to communicate his ideas.

Both Repton and Cullen only built a handful of their hundreds of design proposals. Rather, they operated as image makers and product designers.

\section{The Role of Image Makers in Consumer Culture}

The importance of image makers in consumerist culture is one reason that Repton and Cullen, as image makers, played such a vital role in the production and consumption of landscapes. Daniels posited that Repton's shift to 


\section{Amps}

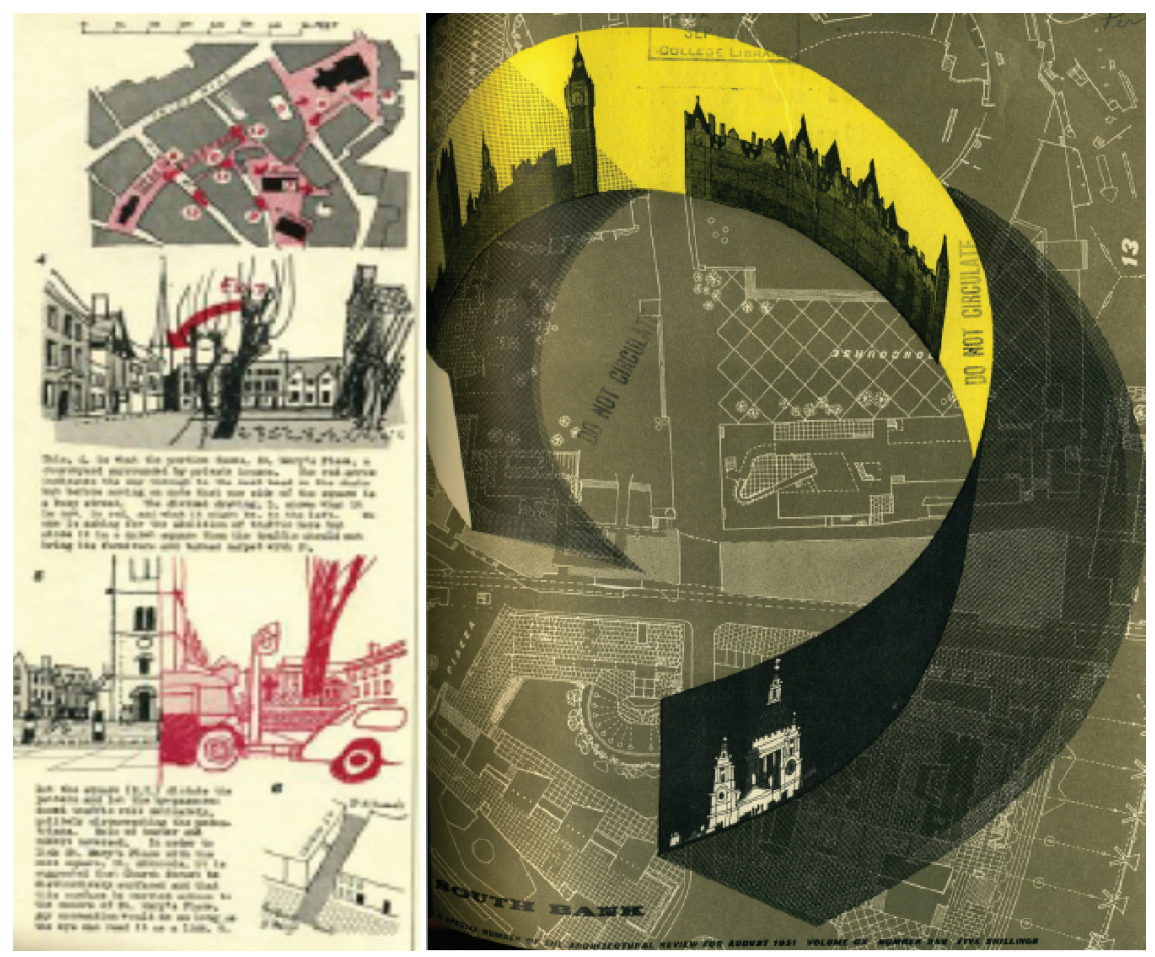

Figure 3. Gordon Cullen, fragment page, from "Midland Experiment: Shrewsbury," Architectural Review, May 1954 (left); Gordon Cullen and D. Dewar Mills, cover design, Architectural Review, August 1951 (right). Source: The Architectural Press.

landscape gardening "was clearly part of the culture of consumption of image and display, and its allure to capricious consumers, especially whimsical women." ${ }^{17}$ Commercialization of landscape was tied to scenic illusionism and the burgeoning visual culture, in which the status of image makers became central. Landscapes as status, entertainment, and aesthetics translated the vogue of seventeenth-century landscape paintings into three-dimensional space, fueling and fulfilling the aspirations of the polite society. Rogger, who studied Repton's working practices and his image and book products, instead of his design proposals proper, argued that Repton "integrated his landscape enterprise into a much broader 'culture of improvement' that permeated public debate of the Georgian era." 18 He wittingly considers Repton "a draughtsman," whose publication and publicist activity were the primary activity that left a more lasting legacy than his built gardens and designs themselves. ${ }^{19}$

The intensification of visual consumer culture in the mid-twentieth century pushed the status of the image-making trade to new heights. In his seminal book, The Society of the Spectacle (1967), Debord observed that society had 


\section{Amps}

become one of spectacle, in which images replaced the perceptible world. These images trumped lived experiences, and what once was directly lived became mere representation. "The language of the spectacle," Debord argued, "is composed of signs of the dominant organization of production - signs which are at the same time the ultimate end-products of that organization." ${ }^{20}$ By this line of thinking, the flood of images in advertising, TV, film, and print media became both the chief products ("image-objects," in Debord's terminology) of and the essential tools for mediating social exchange and for instilling in the consumer the urge to buy. Spectacle drove this development, bolstering the commodity market by spurred consumer desires.

In characterizing the spectacle, Debord reserved a crucial spot for image makers and publicity. He contended that in a society of spectacle, the originators of ideas are often superseded by the originators of images. The importance of image makers, thus, is one reason that Cullen, as an image maker of the Review's Townscape, played such a vital role. As one of the earliest alternatives to the modernist functional city model, the visual-based Townscape model ushered in an urbanism whose chief imperative was vision, and whose most vital agents were image makers. From among his colleagues, Cullen most effectively reified and manufactured the editors' Townscape as a commodity for a society of spectacle. His modus operandi gave expression to the spectacle of the modern-picturesque urban landscape or townscape in the context of postwar urbanism. Through his art editorial work, Cullen and other visualizers, marketers, and publicists became champions of the society of the spectacle, streamlining architecture within the economic, media, and social forces that Debord's observations decried.

Because of their clever use of pictorial genres and graphic techniques, as well as their shrewd business-mindedness, Repton and Cullen were uniquely able to fashion new country and town landscape commodities to the contemporaneous market. The discussion below of Repton's and Cullen's working modes, marketing strategies, and image-making tactics is a methodological research sampler, not an exhaustive list.

\section{Adaptable Working Modes: Market, Media, Publicity, and Branding}

The two men built up their patrons and audience by "reading" the market and adapting their working modes and products to fit the consumer. They operated similarly to the architect Le Corbusier, whose renown rests both on his design ingenuity and his mastery of self-branding, publicity, and audience building, as Colomina and de Smet demonstrated in their writing. ${ }^{21}$

The Market. Repton catered to and served both the Whigs and the Tories the educated nobility and large landowners who inherited social status, and the rising sector of industrialists and businessmen who sought class mobility through stylish estates and in the acquisition of good taste. In Sketches and 
Hints he referred to the Tories as gentlemen who were not fortunate to be educated in the fine arts. He was at ease communicating with women, who saw their role extending from the domestic realm to the estate grounds and hired his services. Repton also recognized the budding landscape gardener professionals and botanical amateurs who sought practical yet tasteful design principles (Figure 4). To appeal to these diverse groups he assumed two roles: as a tastemaker authority who advises and teaches his patrons to see and imagine future landscape improvements, and as a mediator between erudition and practice who translates tasteful ideas into professional design principles and practical rules. As Rogger posited, Repton's premise and novelty was "in uniting the qualities of businessman and man of taste, a mandate he adopted for his landscape gardener identity."22 From 1804 onward his clientele became wider and more diverse, including middle-class country-house owners lacking education and taste. Importantly, he compromised on principles of one style in favor of diverse styles to more flexibly accommodate differing tastes and economic means as well as appeal to mainstream practitioners. ${ }^{23}$ Repton's legacy has not been as a great landscape designer and builder but as a builder of patronage, audience, and readership. He bridged between the erudite theoretician and art connoisseurs and the professional gardener, and between the elite and the new bourgeoisie.

As a commercial artist, Cullen was adept at producing artwork for diverse clients, such as manufacturers, government agencies, professional organizations, and publishers. His promotional drawings for architectural offices targeted a growing readership of architectural magazines that included lay people who later viewed his work in the Review. As art editor, he recognized a new consumer market: the nascent postwar town planner and urban design professional. Hence, Cullen served as a mediator between the Townscape

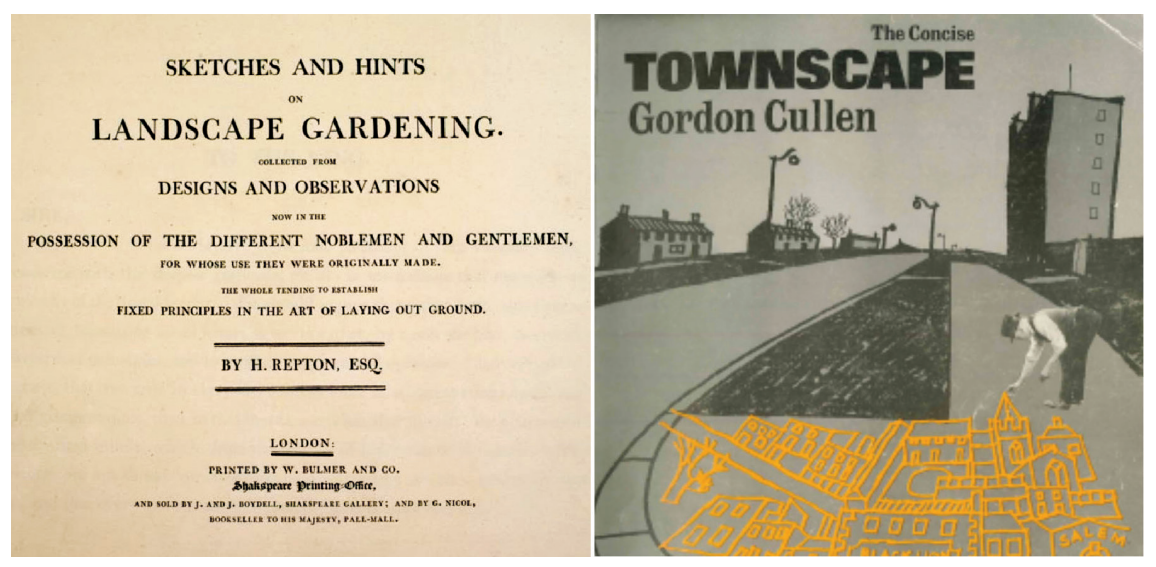

Figure 4. Repton, title page of Sketches and Hints on Landscape Gardening (1794) (left). Public domain; Cullen, book cover, The Concise Townscape (1971) (right). Reproduced by permission of Taylor \& Francis Books, UK. 


\section{Amps}

theory of his journal editors and those who would put that theory into practice by formulating intelligible images, principles, and methodology. $\mathrm{He}$ created benign, amusing images that would appeal to mainstream practitioners, and discarded traditional laborious drafting and the lofty language (with its elitist and nationalistic bent) of the editors, replacing them with affable cartoonish line drawing and everyday language with an empathetic bent that appealed to the modern consumer. In the decades following his departure from the Review Cullen also catered to two other consumer groups: 1. design students who sought to imitate Cullen's freehand drawings; 2. professionals and civic conservationists of the countryside and towns who sought lucid approaches and visualization of their ideas. His townscape consulting work in the 1960s and 1970s addressed these demands (Figure 4).

Media and publicity. The two men were publicity driven. They were versed in the up-to-date mass media apparatus and printing technology, maintaining close relationships with publishing and broadcasting trades, especially press printers and colorists. Repton's private Red books were hand-drawn and written, water-colored, and manually bound. He had his own small atelier where several assistants helped with the production. His commercial publications, however, took advantage of advances in typeset and image reproduction. For colored image imprint, Repton used the latest aquatint engraving, a reproductive technique for added realism, most suitable for landscapes. These productions were still expensive, and it was not until further inventions in letter setting and paper and reproduction technology that the production became expedient and thus economical for wider distribution. ${ }^{24}$ Thus, cost-effective reprints of Repton's books would be left to his successor, J. C. Loudon, a landscape designer, horticulturalist, entrepreneur, and publisher in his own right, who was instrumental in fostering Repton's lasting legacy. ${ }^{25}$

Cullen's performance was intricately linked to the printing press and mechanical reproduction in the postwar consumer economy, especially architectural periodicals that enjoyed international distribution and whose images widely circulated in the vast stream of mass media. For Cullen, the press and print media were a new context of production, existing in parallel with the construction of the city itself. He worked with the production team at the Architectural Press, taking advantage of the up-to-date modern color and photographic reproduction. ${ }^{26}$ Cullen exploited the new artistic and practical opportunities of photography, including photomontages and the use of trace over "contact" sheets to project his ideas. His reputation hinged on the power of his images (and to some extent the text) as they circulated in the stream of mass media, often detached from their initial message and context. This is evident in the extensive references and displays of his drawings in the company of architects of diverse and even competing views. The ability to make inroads into the works of practitioners of all schools - modernists and 
postmodernists, romantics and realists, pragmatists and intellectuals - is a Cullen hallmark.

Branding the persona. As noted above, Repton constructed his persona as a taste authority and became a public figure and household name among the upper echelon of the English society. His publicity depended on personal interactions and communication with patrons and publishers, as well as on participation in the contemporary intellectual discourse. ${ }^{27}$

Unlike Repton, Cullen preferred to remain behind the scenes. With the exception of a few invited publications, and brief personal correspondences and collaborations with several prominent academics, his Review essays and illustrations and his book Townscape were the only "active" agents and pollination sources of his work. It was mostly a one-way transaction. The images and, to a limited extent, the words in his essays and book, were mostly responsible for the transmission of his ideas and the construction of his persona. With the exception of his direct tutorship of avid students of urban design, primarily in the 1970s, Cullen the man remained in the background, refraining from actively participating in professional and academic discourse. Yet, the web of interrelated architectural discourses, of which Cullen's work was naturally a part, was vast, and it expanded and permeated other academic fields that were developing postmodern theories in the 1960s onward. Cullen was therefore linked not only to the allied disciplines of urban design, planning, and landscape architecture, but also to the fields of cultural geography, behavioral psychology, phenomenology, and semiotics among other areas. ${ }^{28}$ The openness of his work to a multiplicity of readings is the source of its wide and lasting influence and continued relevance.

Product line. Reaching new and expanding markets in a consumer-driven economy involves creating diverse and new products. Repton packaged his landscape improvement proposals into several graphic-textual products. For his wealthy patrons, he produced the Red Books. For patrons who simply wanted advice he merely prepared a memorandum. For the professional landscape gardener, he produced relatively inexpensive book editions. He is explicit about the economy of his book production and audience in his books' introductions (i.e., advertisements). Finally, he produced illustrations for publications by others, thus reaching new audiences. Acting as a consultant with varied products led him to charge his clients accordingly. Repton billed his patrons three separate rates: for travel time, time spent on the premises, and the Red Book or proposal report. ${ }^{29}$ The Red Books were the most expensive item.

When he joined the Review, Cullen left behind a constant, exhausting battle for clients and commissions for a more financially secure workplace at the press. His stable income enabled him to focus on developing his artwork instead of worrying about his next commission. Still, Cullen joined the journal on the condition that he work three-quarters' time so he could 


\section{Amps}

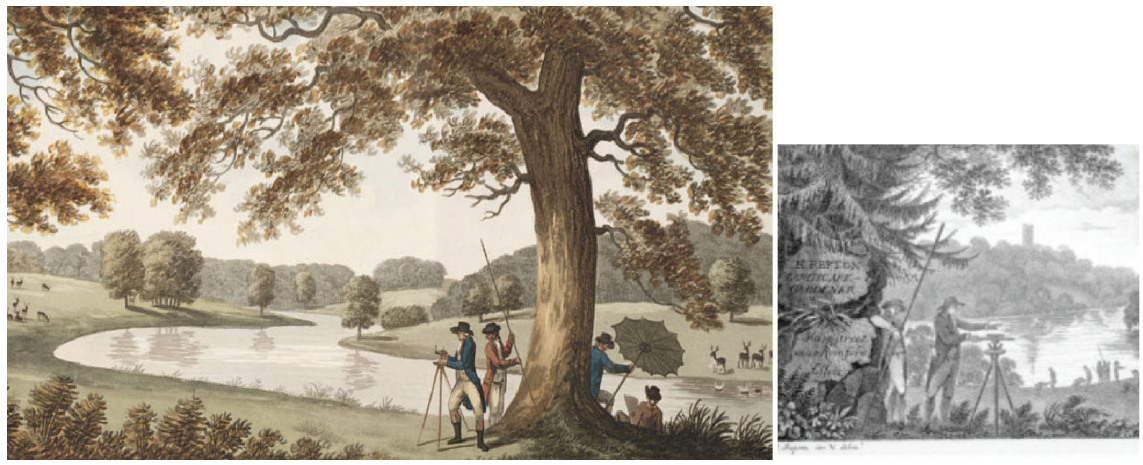

Figure 5. Humphry Repton, "recycling" parts of drawings as seen in trade card and a fragment of hand-colored aquatint, Sketches and Hints on Landscape Gardening (London: W. Bulmer and Co, 1794) (left). Plate XI "A View of the water, and some of the large oaks, at Welbeck" (right). Courtesy, the Winterthur Library: Printed Book and Periodical Collection.

take on outside commercial work, a decision that may have been intended to provide an economic safety net..$^{30}$ Cullen's production as art editor was prolific, both in terms of art work and illustrated essays. Once he left the Review he produced dozens of townscape reports, but only one book, and its concise edition. Archived documents around the time the concise edition was readied point to hopes for a more ambitious book that were foiled. ${ }^{31}$ The Concise Townscape, clearly anticipated that the fast-track facsimile reproduction would be more accessible to students and practitioners and revitalize his old message, and thus became a popular trade edition. ${ }^{32}$ Still in print, it seized a large unfulfilled market, and did so through the highly calculated product design originally produced in his Review and through Townscape.

Editorial salvage or "cut-and-paste." Publishing and broadcasting often rely on "editorial salvage" - the recycling and repackaging of old materials. Repton repackaged the textual and pictorial excerpts from his Red Books for his commercial books. He also "recycled" his drawings or parts of his drawings in multiple engraving plates (Figure 5). For Cullen, editorial salvage had its practical and even philosophical motives. Postwar innovations in printing technology underscored the conceptual shift that was occurring in the market economy, but economy of reproduction and expediency of printing had been Cullen's guiding principles since his early career in the Depression era. For Townscape, Cullen lifted, assembled, and repackaged his essays and drawings that were previously published in the Review, and for most of his images he used bits and pieces from his and other people's ready-made drawings and photographs to both modernize and expedite production. He collected newsprint and magazine cut-outs in scrapbooks, and photographs or "visual precedents" in "case books" for future use (Figure 6). ${ }^{33}$ 


\section{Amps}

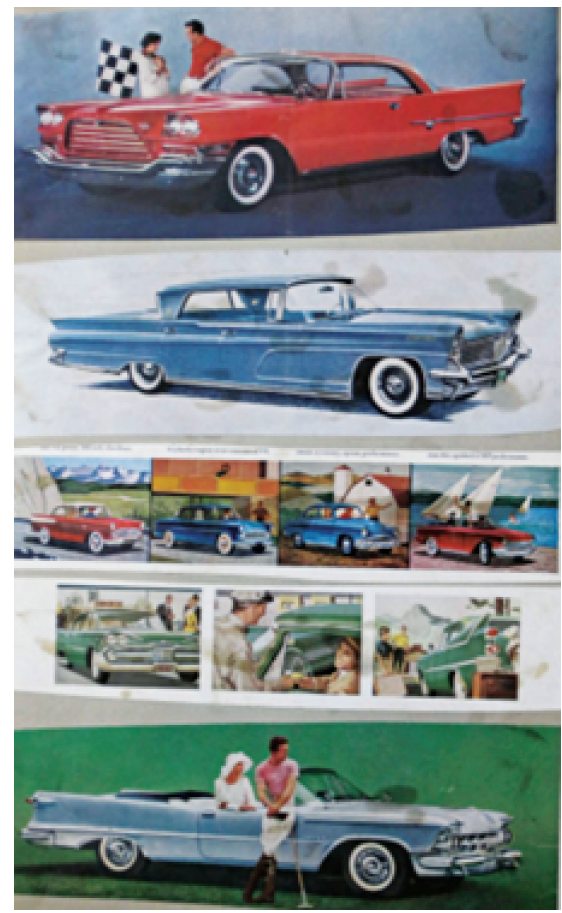

Figure 6. Cullen, scrapbook magazine clippings, 1930s. Source: Cullen personal archive.

\section{Visual Marketing: Illusionism and Myth}

Visual marketing integrates visual psychology to elicit consumer desire to buy a landscape product or subscribe to a landscape lifestyle. For their marketing, Repton and Cullen used visual tricks or illusion and incorporated myth.

Visual tricks and illusion. Repton and Cullen specifically sought to produce an emotional impact with their visuals. Repton described his landscape vistas as "effects" of pleasure; Cullen referred to "drama" and "frisson." These effects prompted contemporary critics to cast both men's works as superficial and marked by trickery. ${ }^{34}$

Repton's Red Books became a nationally recognized brand. They were objects of visual feat and fascination, valued as albums of views and centerpieces for living-room conversation. Well acquainted with theatrical special effects, Repton used framing and screens, elements from stage set design, to induce surprise and awe. His most inventive tactic was the before-and-after flap device - a layered perspective image showing the existing view on a flap and the proposed view, once the flap is lifted. This before-and-after display 


\section{Amps}

has become the quintessential landscape architectural as well as modern advertising technique (well before the invention of Photoshop) (Figure 7). Cullen also deployed the before-and-after effect, but instead of the flap he juxtaposed a pair of images: black-and-white photograph for the existing condition and photomontage/photo-drawing composite for the proposed. And instead of blending the proposed change seamlessly, Cullen's photomontages emphasized the artificiality of the design intervention (Figure 7).

Myth construction. Eliciting consumer desire requires the creation of a myth. Architectural theorist Adrian Forty argues that every successful marketable product embodies innumerable myths about the world, and that these myths over time "come to seem as real as the products in which they are embedded." 35 Thus Repton's drawings preserved the myth that the countryside retained its picturesque quality at a time when new agricultural practices and landholding were erasing rusticity and quaint scenery. Cullen's images seeded the notion that a city shaped according to the principles of Townscape would remain pedestrian-friendly, sociable, and fun, even as the city lost its battle with the automobile, suburbia, and shopping malls. To thrill his readers, Cullen created whimsical townscape spectacles that dressed up urban gloom in a luminous and convivial glow.
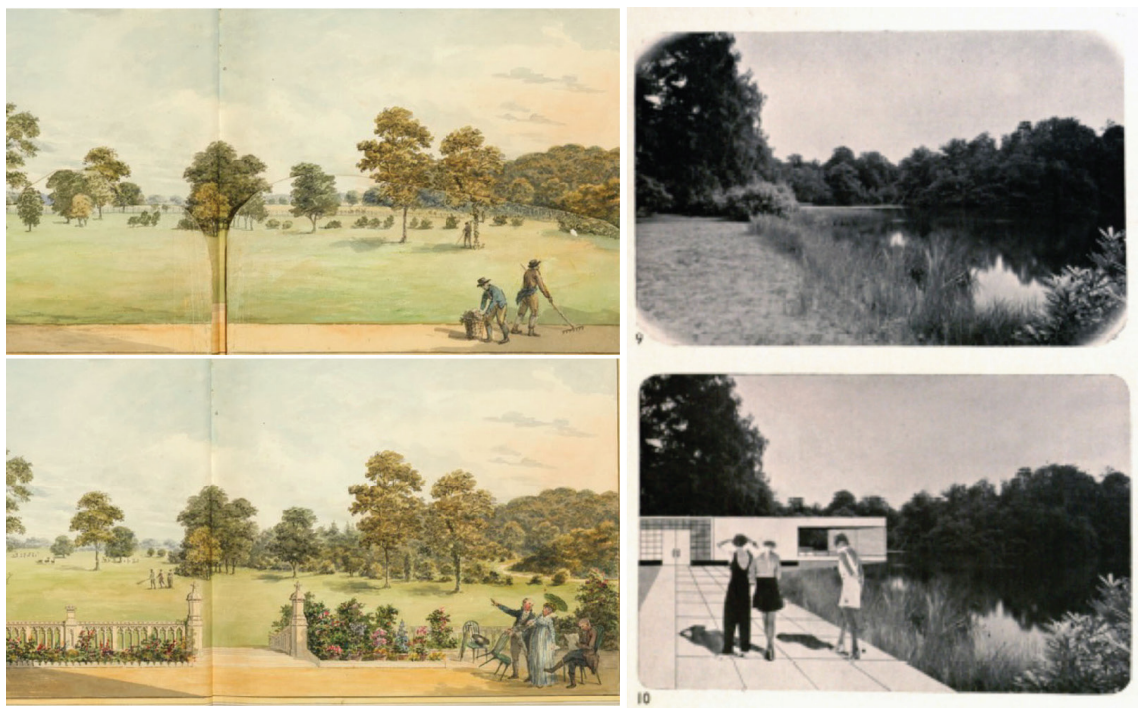

Figure 7. Repton, fragment of watercolor drawing from a report of the gardens at Ashridge showing before-and-after scenes from the house and terrace looking south, respectively, submitted to the Earl of Bridgewater, 1813 (left). Source: The Getty Research Institute, GRI Digital Collections, open access; Cullen, photograph ('before') and photomontage ('after') for "The Case for the Common Garden," by Christopher Tunnard (1938) (right). Source: Cullen personal archive. 


\section{Amps}

\section{Image Making: Mixing Pictorial Genres and Graphic Techniques}

Developing a successful landscape commodity for diverse audiences requires a range of pictorial choices. The two men appealed to their audience by borrowing and mixing art genres, tailoring their drawings to accommodate the target audience. The use of perspective sequence and motion and lighting effects are key to their art.

A mixture of art genres. The two borrowed and combined pictorial techniques from both low- and highbrow art genres, notably painting and theater or film in Cullen's case, creating an alternative to the rigid conventional architectural representation. The effects were palatable and refreshing to wider audience. Repton combined the traditional landscape painting compositions with contemporary free-hand watercolor techniques and theatrical framing devices. Cullen mixed modern and traditional art and landscape architectural drawing techniques, and further blended them with the shifting views of film and the surprise elements of advertising. To this he added the whimsy of cartoons, thus appealing to the postwar generation who grew up with Disney and comic books (see Figure 3).

Perspective (over plan). Repton and Cullen hardly drew plans: they drew mostly perspectives for future effects, but ignored the linear perspective. Repton's use of perspective drawings rather than maps to show landscape improvements, unlike Capability Brown and other predecessors, recalled human perception and made the image intelligible to the non-professional. His perspectives ignored the strenuous drafting of the Renaissance architectural linear perspective and instead followed the free-hand fluid lines of the picturesque landscape drawing craze. In their printed books, Repton also used simple diagrams and sections to aid the professional gardener to achieve the proposed effect.

Cullen modernized, flattened, and further relaxed Repton's perspective. The affordability of cameras and photographic reproduction enabled Cullen to expand his pictorial repertoire, including photomontages, and to move his drawing art forward, to supplement rather than repeat the photograph. Photography liberated Cullen, freeing his drawing from Repton's realistic depiction and allowing it to evolve to a more modern medium, in which he could convey new ideas using spare and whimsical line. He used the camera to reframe and refocus reality; he used illustrations to abstract and make reality fictive, as in advertising.

Motion and passage of time. The sensation of motion and time are central to the art of the two men. Repton's understanding of the emotional impact of theatrical effects led to his depiction of motion and change in landscapes by presenting sequential changing views along a line of movement, typically, from the estate gate to and from the house of his patron. More importantly, 


\section{Amps}

he intended to create a scenic and cinematic sensation of movement through space, to set apart the experience of landscape from that of painting, and even theater. To further enhance the sense of reality and luminosity, Repton mastered the translucent quality of water coloring. In his book, Fragments (1816), he described an experiment with shades of brown and cool gray for different effects through the day. He wrote: "I could avail myself of this discovery to facilitate the mechanical process of printing and colouring many thousand plates, to make a facsimile of my sketches: this I shall endeavour to explain by the annexed two Landscapes, which are supposed to represent the same scene before and after sun-rise; that is, before and after the natural process of colouring takes place" (Figure 8). ${ }^{36}$

Cullen, too, depicted townscapes from the changing perspective of a pedestrian. Anchored in a body strolling through the townscape, the city turned into cinematic experience through his signature "serial vision," a technique of putting sequential views in perspective drawings (Figure 9). Furthermore, Cullen mastered the drama of a black and white range, using it to maximize contrast and depth, and then added "moving colours and shapes." The red buses or "red spots" or banners and flags in his drawings were "exhibition pieces," setting the urban theater in motion. ${ }^{37}$

\section{Captivating the Reader: New Literary Genre and Textual Strategies}

To reach broader audience, Repton and Cullen created a new literary genre by combining existing genres and employing textual devices intended to both enamor and activate the reader. They also considered the ease and manner of the reading practice itself. Moreover, textual strategies involving colloquial language, prescriptive, and metaphorical language and a deliberate layout that produces independence of image and text make their book products accessible and appealing to wide readership.

A mixture of literary genres. As with their images, both men mixed existing traditional and contemporary literary genres. Repton's Red Book was a unique text-image medium and a new gardening genre, combining three sources: travel guides, amateur drawing books, and gardening treatises with architectural proposals or reports. ${ }^{38}$ The descriptive narrative sequence, as in a travel guide, followed the sequence of the colored drawings, each of which was printed on a full page and often a double-page, as in a drawing book. Repton combined these genres with the prudence of gardening treatises, paying special attention to planting composition, shape, and color and seasonal change, as well as the landscape improvement report - a record of the discussion about and analysis of the premises and the proposal, all in hand written notes (see Figure 1). The five commercial books he published based on the Red Books were mostly text-based with a few illustrations theory combined with principles and practical rules, at times bordering an instruction manual. 


\section{Amps}

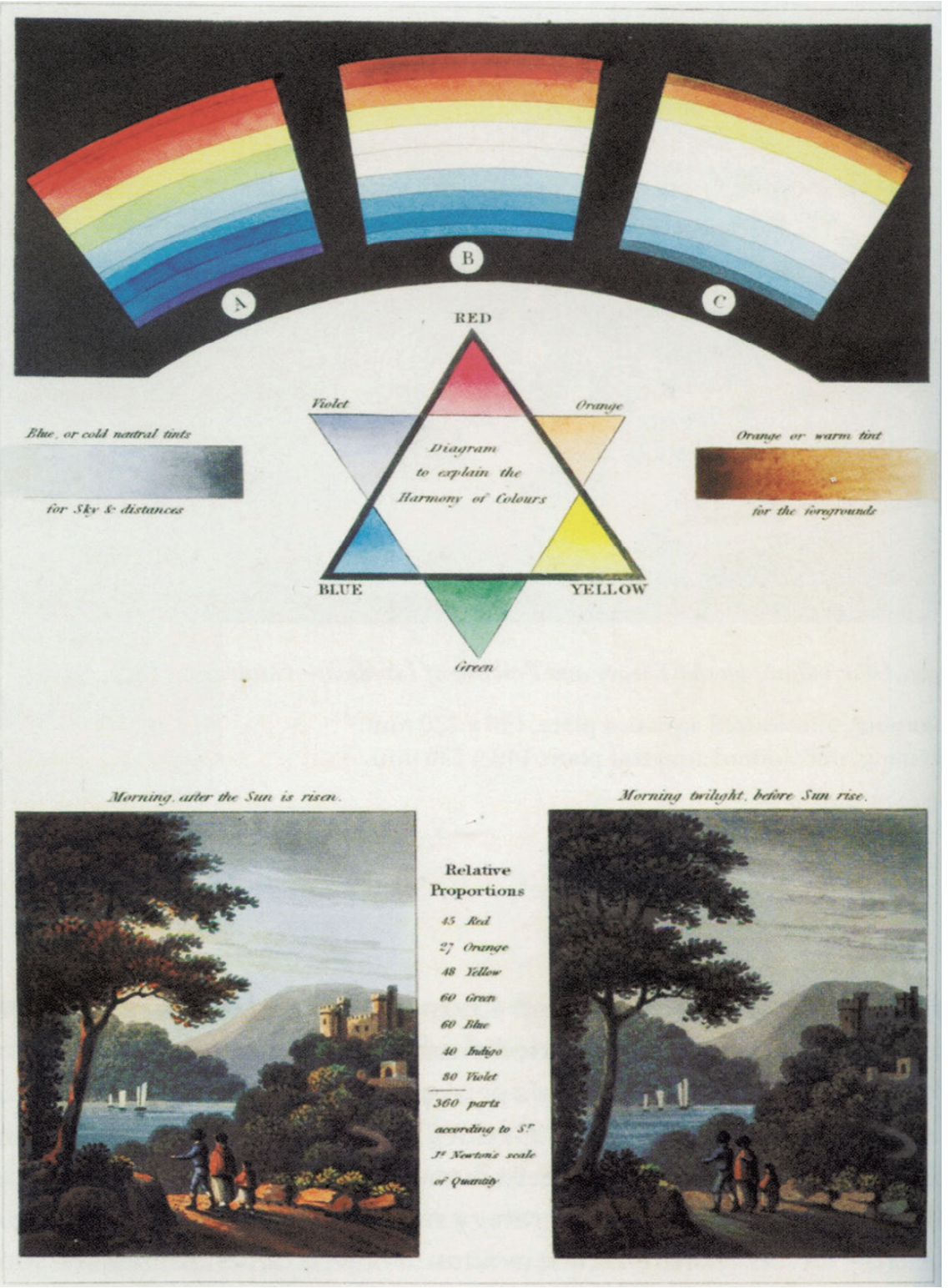

Figure 8. Repton, illustrations of experiment with watercolor shades to depict different daytime, aquatint page spread, Fragments on the Theory and Practice of Landscape Gardening (1816). Source: Research Library, The Getty Research Institute, Los Angeles, CA. (94-B6187), open access. 


\section{Amps}

\section{CASEBOOK： SERIAL VISION}
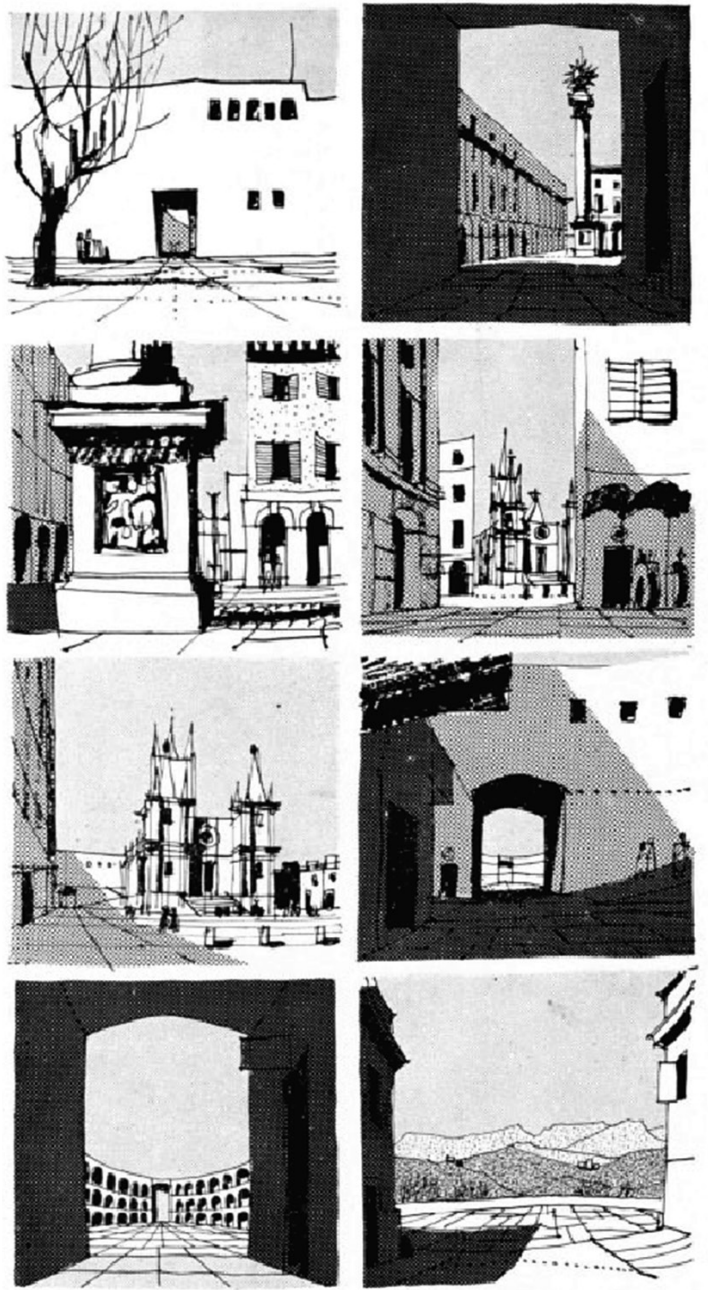

To walk from one end of the plan to another, at a uniform pace, will provide a sequence of revelations which are suggested in the serial drawings opposite, reading from left to right. Each arrow on the plan represents a drawing. The even progress of travel is illuminated by a series of sudden contrasts and so an impact is mads on the eye, bringing the plan to life (like nudging a man who is going to sleep in church). My drawings bear no sclation to the place itself; I chose it because it seemed an evocative plan. Note that the slightest deviation in alignment and quite small variations in projections or setbacks on plan have a disproportionally powerful effect in the third dimension.

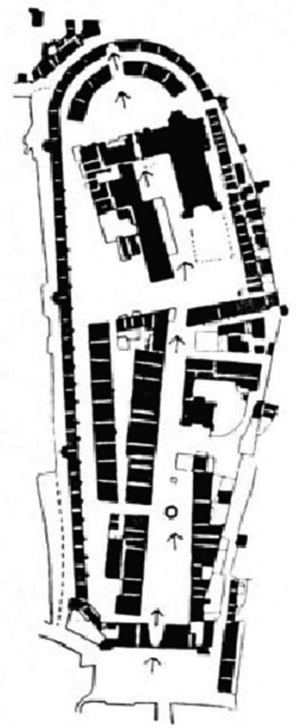

Figure 9. Cullen, "Serial Vision," the opening page of the Casebook section of Townscape, 1961, reproduced by permission of Taylor \& Francis Books, UK.

In Townscape, Cullen also created a genre of its own by combining three genres that rose to dominance in the postwar period: practical manuals for professional architects and town planners, picture books for laypeople, and travel-walking guides. ${ }^{39}$ Many of the Review essays take on the form of an experiential narrative itinerary along town streets and squares. Instead of the codes and measurements of conventional manuals, Cullen drew attention to vision and human perception principles. He then collected these essays into 


\section{Amps}

three book parts - General Studies, Town Studies, and Proposals - and added an introductory part, which was a visual database and vocabulary builder for good and bad townscape examples, entitled "Casebook." 40

Reader's ease and interactivity. The two men considered the experience of the reader, as well as the reading practice itself. For example, Repton's "flaps" physically engaged the reader. The Red Books served not only as coffee-table entertainment but had a consultation role to the client, who could implement pieces of its recommendations as fragments/phases over time. For his commercial books, Repton developed a detailed table of contents in order to enable the reader to skip text and go directly to the image or subject.

Cullen's "casebook" was codified database, a kind of "hyper-link" for making connection between the database and the design principles in the essays. Moreover, he used "expanded captions" for readers with disinterest in long texts. Townscape in particular was not designed for passive enjoyment of pictures; rather, it offered a way of thinking and a stock of tools. Cullen's favorite metaphor for the book was that of a game, with playing parts (the visual precedents) followed by gambits and moves (the individual essays), which shapes not only the underlying structure of the book but also how the text should be read. ${ }^{41}$ There are no ordered steps or prescriptions and no dice; the play instructions are but principles. Cullen encouraged his reader to assemble a personal collection of photographic precedents, and then to construct customized paths to visualize and design the city.

The above consumerist aspects of landscape production and consumption are not an exhaustive list. Book design, textual strategies, and other media communication venues that the two men engaged, such as exhibitions, are not covered here because of length limitation.

\section{The Merits and Limits of the Consumerist Interpretive Framework}

The above interpretive framework and research methodology aim to draw attention to commercial agencies that have shaped the history of landscape and townscape design. It shows that publicity and marketing have been key to landscape history, even when the celebrated creator was not a builder, as were Repton and Cullen, or an accomplished draftsman, as was the nineteenthcentury landscape architect Frederick Law Olmsted. Olmsted's publications and political shrewdness, aided by the drawings of his partner, Calvert Vaux, led the way for his fame and influence. Likewise, J. C. Loudon's publications, rather than his design work or drawings, yielded a special place in the history of the English garden.

This framework also provides tools for an expanded discussion on representation techniques and tactics that enable us to revisit the history of landscape production and reception. As I have shown elsewhere, the remarkable 


\section{Amps}

work of Repton and Cullen continues to exert unrecognized influence, both directly on landscape-drawing techniques and indirectly on recent advances in digital media, and hinges on the vast number of images floating in the stream of mass media and often detached from their initial concepts. ${ }^{42}$

Finally, this framework opens up ethical and ideological questions about the relationship between consumerism and landscape design practice. A key question concerns the measures of success. In a consumerist market success is measured quantitatively (i.e., money, popularity, or stardom); in an ideal design, it is measured qualitatively (i.e., health, justice, and environmental sustainability). This question is important, yet it is also useful to unmask consumerist forces that determine the accepted canon of landscape history before exerting moral judgment.

The dependence of landscape design on its consumer environment and mass media is inevitable. And it is vital for us to understand that landscape products operate in the competitive marketing environment that "sells" lifestyle or attitude, and that ultimately shapes the landscape. To be effective as scholars of landscape design, we need to understand the socio-economic underpinnings of our design work, the practicalities that accompany and often affect the creative side of the profession. Leveraging consumerist arts is often the only way that landscape architects can promote ambitious projects and ideas.

With the above two examples, I have illustrated the tight, perhaps necessary, connection between landscape design craftsmanship and salesmanship. These two designers could not have achieved such professional impact had they not also possessed uncanny marketing and media savvy. As scholars, we owe it to them and ourselves to recognize that relationship, and to understand the ways in which such tactics shape landscape discourse, practice, and lifestyle.

\section{Notes}

1 Humphry Repton, Sketches and Hints on Landscape Gardening (London: J. Boydell, 1794), x.

2 Humphry Repton, An Enquiry into the Changes of Taste in Landscape Gardening (London: J. Taylor, 1806), iv.

3 Allen J. Scott, "The Cultural Economy: Geography and the Creative Field," Media, Culture \& Society 21, no. 6 (1999): 807.

4 For a broad discussion on garden history approaches, see John Dixon Hunt, Garden History: Issues, Approaches, Methods (Washington, DC: Dumbarton Oaks Research Library and Collection, 1992), 1-3.

5 Repton's design proposals, or "landscape improvement" in his terms, were packaged in luxurious books hand bound with Chinese red morocco, hence dubbed Red Books.

6 Guy Debord, Society of the Spectacle, trans. Donald Nicholson-Smith (New York: Zone Books, 1995 [1967]); Adrian Forty, Objects of Desire: Design and Society, 1750-1980 (London: Thames \& Hudson, 1986). 
7 Beatriz Colomina, Privacy and Publicity: Modern Architecture as Mass Media (Cambridge, Mass.: MITPress, 1994); BeatrizColomina, "Architectureproduction," in This Is Not Architecture: Media Constructions, ed. Kester Rattenbury (London: Routledge, 2002), 207-21.

8 Catherine de Smet, Le Corbusier, Architect of Books. Trans. Deke Dusinberre (Baden, Switzerland: Lars Müller, 2007).

9 John Dixon Hunt, "Sense and Sensibility in the Landscape Designs of Humphry Repton," in Gardens and the Picturesque, ed. J. D. Hunt (Cambridge, Mass: The MIT Press, 1992a), 138-66.

10 Stephen Daniels, "Scenic Transformation and Landscape Improvement: Temporalities in the Garden Design of Humphrey Repton," in Representing Landscape Architecture, ed. Marc Treib, 42-55 (Trowbridge, Wiltshire: Cromwell Press, 2008); André Rogger, The Art of Humphry Repton's Red Books (Milton Park, Abingdon: Routledge, 2007).

11 David Gosling, Gordon Cullen: Visions of Urban Design (London: Academy Editions, 1996).

12 Stephen Daniels, "Scenic Transformation," 47. According to Daniels, Repton was a lifelong fan of theater of all kinds, including pantomimes, masquerades, private theatricals, and the highly staged performances in polite venues.

13 Jane Austin, Mansfield Park (London: T. Egerton, 1814).

14 Interview of Jacqueline Cullen by the author, Wraysbury, July 2010.

15 Humphry Repton, Sketches and Hints, xiii.

16 The Review's editors who were central to the formulation of townscape-a postwar modern-picturesque city model - were the owner and chief editor, Hubert de Cronin Hastings, the historian Nikolaus Pevsner, and the theorist J. M. Richards. For a study on Cullen's roles and status in the journal, see Mira Engler, Cut and Paste Urban Landscape: The Work of Gordon Cullen (London: Routledge, 2016), $88-96$.

17 Daniels, "Scenic Transformation," 49.

18 André Rogger, The Art of Humphry Repton's Red Books (Milton Park, Abingdon: Routledge, 2007), 12.

19 Ibid., 65.

20 Debord, Society of the Spectacle, 13.

21 Colomina, Privacy and Publicity; Colomina, "Architectureproduction"; de Smet, Le Corbusier.

22 Rogger, Humphry Repton's Red Books, 9.

23 Engler, Cut and Paste, 166.

24 Frank Jenkins, "Nineteenth-Century Architectural Periodicals," in Concerning Architecture, ed. John Summerson (London: Penguin Press, 1968), 153. The age of architectural periodicals emerged and Pattern Books for professionals became popular with the mechanization of paper manufacture and printing as well as improved mail delivery in the 1830s. For discussion on printing technology inventions and architectural magazines, see Mary Woods, "The First American Architectural Journals: The Profession's Voice," The Journal of the Society of Architectural Historians 48, no. 2 (June 1989). 


\section{Amps}

25 J. C. Loudon, Repton's successor, dedicated the first of his five-volume comprehensive landscape gardening series to "Repton's School," because it both combined "all that was excellent in the former schools" and opposed "the adoption of one style, school, or system, as better than all the others" (Loudon, 1835, p. ix).

26 The Review's Color Line printing technique, also known as "letterpress," printed only one color at a time and produced planar and industrial effects, which aligned with Cullen's preferred modern aesthetics.

27 See, for example, his lengthy correspondence with the landscape aesthetician Uvedale Price, who theorized the picturesque landscape school. Repton's letter to Uvedale Price comprised the appendix of his first book Sketches and Hints.

28 Applications of Cullen's work are also found in ergonomics design, website design, and wayfinding in graphic design, among other disciplines. See Engler, Cut and Paste, 219-23, 230-3.

29 Rogger, Humphry Repton's Red Books, 65.

30 Gordon Cullen, personal archive, journal, April 15, 1960, \#670. He was hired in 1946 at a fixed salary of $£ 750$ per year. When he left fourteen years later his salary was $£ 1,450$ a year, which according to Cullen had simply kept up with the cost of living.

31 Gordon Cullen, personal archive, \#340.

32 In the introduction to The Concise Townscape, Cullen alluded to having been told to consider additional material or new examples, but justified his refusal on practical grounds, arguing that there were few good examples in postwar construction, and that tracking them would have made the investment of time "quite uneconomical." Gordon Cullen, The Concise Townscape (New York: Van Nostrand Reinhold, 1971), 13.

33 Engler, Cut and Paste, 37-42.

34 For example, the landscape aesthetician and art connoisseur Richard Payne Knight ridiculed Repton for lacking connoisseurship (though not for lacking pictorial sensibility) and considered his work as a dumbing-down process, a taste for theatrical scenery that reduced the landscape of the Old Masters. Cullen's drawings were often criticized as overly seductive and his writings as plain, vague, and hardly intellectual.

35 Forty, Objects of Desire, 9.

36 Humphry Repton Fragments on the Theory and Practice of Landscape Gardening (New York: Garland Pub, 1982 [1816], 49-52.

37 Gordon Cullen, "Townscape Casebook," The Architectural Review 106, no. 636 (December 1949): 368.

38 Rogger, Humphry Repton's Red Books, 8.

39 Engler, Cut and Paste, 166-85.

40 For a broad discussion on the genre makeup of Townscape, see Chapter 3 in Engler, Cut and Paste.

41 Gordon Cullen, Townscape (London: Architectural Press, 1961), 15.

42 For a broad discussion on the influence of Cullen's landscape drawing techniques on recent advances in digital media, see Chapter 4 in Engler, Cut and Paste. 


\section{Amps}

\section{Bibliography}

Archer, John. The Literature of British Domestic Architecture 1715-1842. Cambridge, Massachusetts: The MIT Press, 1985.

Colomina, Beatriz. Privacy and Publicity: Modern Architecture as Mass Media. Cambridge, Mass: MIT Press, 1994.

Colomina, Beatriz. "Architectureproduction." In This Is Not Architecture: Media Constructions, edited by Kester Rattenbury, 207-21. London: Routledge, 2002.

Cullen, Gordon. "Townscape Casebook," The Architectural Review 106, no. 636 (December 1949): 363-74.

Cullen, Gordon. Townscape. London: Architectural Press, 1961.

Cullen, Gordon. The Concise Townscape. New York: Van Nostrand Reinhold, 1971.

Cullen, Jacqueline. Interview. July 25, 2010. Wraysbury, UK.

Debord, Guy. Society of the Spectacle. Translated by Donald Nicholson-Smith. New York: Zone Books, 1995 [1967].

Daniels, Stephen. "Introduction.” In Humphry Repton: The Red Books for Brandbury and Glenham Hall, edited by S. Daniels, viii-xiv. Washington, DC: Dumberton Oaks Research Library \& Collection, 1994.

Daniels, Stephen. Humphry Repton: Landscape Gardening and the Geography of Georgian England. New Haven: Yale University Press, 1999.

Daniels, Stephen. "Scenic Transformation and Landscape Improvement: Temporalities in the Garden Design of Humphrey Repton." In Representing Landscape Architecture, edited by Marc Treib, 42-55. Trowbridge, Wiltshire: Cromwell Press, 2008.

Engler, Mira. "Detachable Images and the Making of the Postmodern City: The Work of Gordon Cullen," The International Journal of Architectonic, Spatial, and Environmental Design 9, no. 4 (December 2015): 31-54.

Engler, Mira. Cut and Paste Urban Landscape: The Work of Gordon Cullen. London: Routledge, 2016.

Forty, Adrian. Objects of Desire: Design and Society, 1750-1980. London: Thames \& Hudson, 1986.

Gosling, David. Gordon Cullen: Visions of Urban Design. London: Academy Editions, 1996.

Hunt, John Dixon. "Sense and Sensibility in the Landscape Designs of Humphry Repton.” In Gardens and the Picturesque, edited by J. D. Hunt, 138-66. Cambridge, Mass: The MIT Press, 1992a.

Hunt, John Dixon. Garden History: Issues, Approaches, Methods. Washington, DC: Dumbarton Oaks Research Library and Collection, 1992.

Hunt, John Dixon. "Introduction." In Fragments on the Theory and Practice of Landscape Gardening, by Humphry Repton. New York: Garland Pub, 1982 [1816].

Jenkins, Frank. "Nineteenth-Century Architectural Periodicals." In Concerning Architecture, edited by John Summerson, 153-60. London: Penguin Press, 1968.

Lambert, Susan. The Image Multiplied: Five Centuries of Printed Reproductions of Paintings and Drawings. London: Trefoil Publications, 1987. 


\section{Amps}

Loudon, J. C., ed. The Landscape Gardening and Landscape Architecture by the Late Humphry Repton. London: Longman \& Co, 1835.

Repton, Humphry. Sketches and Hints on Landscape Gardening. London: J. Boydell, 1794.

Repton, Humphry. An Enquiry into the Changes of Taste in Landscape Gardening. London: J. Taylor, 1806.

Repton, Humphry. Fragments on the Theory and Practice of Landscape Gardening. New York: Garland Pub, 1982 [1816].

Rogger, André. The Art of Humphry Repton's Red Books. Milton Park, Abingdon: Routledge, 2007.

Scott, Allen J. "The Cultural Economy: Geography and the Creative Field." Media, Culture \& Society 21, no. 6 (1999): 807-17.

Smet, Catherine de. Le Corbusier, Architect of Books. Translated by Deke Dusinberre. Baden, Switzerland: Lars Müller, 2007.

Woods, Mary. "The First American Architectural Journals: The Profession's Voice."

The Journal of the Society of Architectural Historians 48, no. 2 (June 1989): 117-38. 